\title{
Effect of Zeolite Dietary Supplementation on Physiological Responses and Production of Laying Hens Drinking Saline Well Water in South Sinai
}

\author{
Khamis Refaay Said Emam¹, Hossam Mohamed Toraih², Amal Mohamed Hassan², Ahmed Abd-Elatif El-Far \\ Ali Saber Morsy ${ }^{2 *}$ and Nagwa Abd El-Hady Ahmed ${ }^{3}$ \\ ${ }^{1}$ Animal and Poultry Production Department, Faculty of Environment and Biological Agriculture and Food Processing, Beni-Suef University, Egypt. \\ ${ }^{2}$ Animal and Poultry Physiology Department, Desert Research Center, Egypt. \\ ${ }^{3}$ Animal Production Department, Faculty of Agriculture, Cairo University, Egypt. \\ *Corresponding author`s Email: alisaber_drc@yahoo.com; ORCID: 0000-0003-4252-2088
}

\begin{abstract}
This study conducted to investigate the effects of dietary zeolite on egg production, egg quality and blood constituents of hens under drinking saline well water. 180 hens were randomly divided into six equal groups (30 hens / group). $1^{\text {st }}$ group (T), hens drank tap water and fed basal diet. The $2^{\text {nd }}$ group (T1), hens drank tap water and fed diet containing $2 \%$ zeolite. The $3^{\text {rd }}$ group (T2), hens drank tap water and fed diet containing $4 \%$ zeolite. $4^{\text {th }}$ group (S), hens drank saline well water and fed basal diet. $5^{\text {th }}$ group (S1), hens drank saline well water and fed diet containing $2 \%$ zeolite. $6^{\text {th }}$ group (S2), hens drank saline well water and fed diet containing $4 \%$ zeolite. Red blood cells and hemoglobin were significant lower in the hens of S compared to other treatments. Hens of S group showed significant decrease in total protein, globulin, glucose and total antioxidant capacity concentrations as compared to the hens of T and T2 groups. Alanine transaminase, aspartic transaminase and creatinine were significantly increased in the hens of S group compared to other treatments. Aldosterone hormone was significantly decreased in the hens of $\mathrm{S}$ compared to them in T, T1 and T2 groups. Egg weight significantly increased in the hens of S2 compared with hens in $\mathrm{T}$ and $\mathrm{S}$ groups. Egg number and egg mass were significant increase in the T1, T2 and S2 compared to hens in T, S and S1 groups. Hens of T1, T2 and S2 groups had significantly improved feed conversion compared to hens of $\mathrm{S}$ group. Hens of S group had significantly decreased shell thickness compared to other treatments. In conclusion, under drinking saline well water, addition of zeolite to laying hens' diets at levels $4 \%$ might improve productive performance and eggshell quality.
\end{abstract}

Key words: Hematological parameters, Laying hens, Productive performance, Saline water, Zeolite.

\section{INTRODUCTION}

Water is important nutrient for livestock and represents between $55 \%$ and $75 \%$ of the weight of a chicken, $65 \%$ of the egg, about $70 \%$ is inside the cells and $30 \%$ is in fluid surrounding the cells and in blood (Ahmed and Abdel-Rahman, 2004). Quality of ground water depends upon the naturally occurring inclusions such as cations, anions and heavy metals. Scarcity of tap water in such desert areas generated a competition between human and animals. Hence, it is essential to use saline well water as possible supplies for animal's drinking water. In Egypt, saline well water is the main factor determining the suitability of particular water source for poultry and one of the major factors affecting water quality is the amount of Total Dissolved Salts (TDS) in the water. Drinking high amount of TDS may cause harmful effects resulting in poor performance, illness or even death (Morsy et al., 2012 and Amal, 2013). Poultry in desert and newly reclaimed areas probably dependent on drinking saline well water with varying degrees of salinity and such water often contains high concentrations of dissolved minerals salts (Morsy et al., 2016, 2017 and 2018). These high concentrations of minerals can show toxic and ascites and hence cause reduction in laying performance (Julian, 1987). Morsy et al. (2012) reported that high level of minerals in saline water may contribute to the production of defective shells in eggs particularly reduced shell thickness and shell calcium, increased the number of damaged eggs and increased plasma calcium and phosphorus of laying hens. So, cause an economic problem for poultry industry. Blood constituents are changed by drinking saline water (Morsy, 2018; Amal, 2013; Morsy et al., 2012).

In recent years, there are evidences in the literature that using of zeolite (Clinoptilolite) has encouraging effects on the poultry performance (Basha et al., 2016; Wawrzyniak et al., 2017; Morsy, 2018). Zeolite-natural and modified, because of their specific structure, are excellent adsorbed and thus can diminish the harmful effect of heavy metals. Clinoptilolites, due to its structural stability under high temperatures and acidity, are the most widely used zeolite in animal studies. The important research data indicated the positive influence of the in-feed inclusion of clinoptilolite on animal health. Zeolite is an excellent "trapper" of waste products and heavy metals because of its chemical composition 
and specific lattice structure (Pavelic et al., 2001). These minerals are crystalline, hydrated aluminosilicates of alkali and alkaline earth cations ( $\mathrm{Na}, \mathrm{K}$ and/or Ca cations). Zeolite is porous material, able to adsorb molecules of appropriate cross-sectional diameter and to exchange their constituent cations without major change of their structure. Thus, zeolite appears to posse two important properties: adsorption and ion-exchange. The exploitation of these properties underlies the use of zeolite in a wide range of industrial and agricultural applications and particularly in animal nutrition (Beltcheva et al., 2015).

Dietary zeolite improves feed efficiency and egg production in laying hens (Samara, 2003). Moreover, Pavelic and Hadzija (2003) suggested that natural zeolite may have a beneficial effect against aflatoxicosis and other health disorders. Zeolite clinoptilolite is able to adsorb damaging toxins that can potentially reduce the performance of animals (Oğuz and Kurtoğlu, 2000), affect gut morphology, decrease pH, and lower pathogenic bacteria counts, which suggests that intestinal health improvement (Wu et al., 2013). Also, zeolite, being the adsorbents, eliminates a number of toxic substances (heavy metal salts, nitrates, nitrites, mycotoxins, radionuclides, metabolism products) from the organism.

At present, use of natural zeolite develops by utilizing features of ion-exchange, water and gas absorption (Binats et al., 2014). Beneficial effects of zeolite may also be attributed to the silicon, aluminum or sodium content which can influence calcium-metabolism, thus improving calcium and phosphorus utilization (Leach et al., 1990; Watkins and Southern, 1991). It has been demonstrated in a number of studies that the inclusion of zeolites in diets improves weight gains and feed conversion in broilers (Fethiere et al., 1994) and their physical properties (Tserveni-Gousi et al., 1997). Addition of natural zeolite to broiler diet led to promote of chicken performance (Nikolakakis et al., 2013) and improve body weight gain and feed conversion ratio (Debeic, 1994). Boyer (2000) reported that clinoptilolite supplementation led to a significant increase in feed efficiency and reducing the toxic effects of surplus ammonium ions. In contrast, some researchers found that using of zeolite had no effect on poultry production (Evans and Farrell, 1993).

Therefore, this study was to investigate the effects of dietary zeolite (Clinoptiolite) on egg production, egg quality and blood constituents of Golden Montazah hens under drinking saline well water (3398 ppm total dissolved solids) in South Sinai.

\section{MATERIALS AND METHODS}

\section{Experimental region}

The present study was conducted in the South Sinai Research Station, located at Ras Suder that belongs to the Desert Research Center, Ministry of Agriculture and Land Reclamation, Egypt. The experiment started on June 2015 up to August 2015.

\section{Ethical approval}

This experiment was performed according to all ethics and animal rights (Desert Research Center). As much as this work had considering all rules and regulations in conformity with the European union directive for the protection of experimental animals (2010/63/EU).

\section{Experimental animals, feeding and management}

A total number of 180 hens (22- weeks old and body weight of $1629.72 \mathrm{~g} \pm 23.54$ ) were randomly divided into six equal groups (30 hens / group). The $1^{\text {st }}$ group (T), hens drank tap water (containing $265 \mathrm{ppm}$ TDS) and fed basal diet. The $2^{\text {nd }}$ group (T1), hens drank tap water and fed diet containing $2 \%$ zeolite. The $3^{\text {rd }}$ group (T2), hens drank tap water and fed diet containing $4 \%$ zeolite. The $4^{\text {th }}$ group (S), hens drank saline well water (containing 3398 ppm TDS) and fed basal diet. The $5^{\text {th }}$ group (S1), hens drank saline well water and fed diet containing $2 \%$ zeolite. The $6^{\text {th }}$ group (S2), hens drank saline well water and fed diet containing $4 \%$ zeolite. According to Emam et al. (2019), chemical analysis of tap and saline well water was presented in Table 1. Chemical composition of the zeolite (Clinoptilolite) was shown in Table 2 .

\section{Experimental procedures}

Birds until 34 weeks of age (end of experiment) were housed in wire cages, supplied with clean fresh water and fed ad-libitum on recommended standard rations according to NRC (1994) as shown in Table 3. At the age of 18 weeks the natural day length was artificially increased from $14 \mathrm{~h}$ to $16 \mathrm{~h} /$ day in peak of egg production (30 weeks) and then it maintained constant until the end of experiment. Birds were kept under the same managerial and hygienic conditions. Birds were healthy and examined against diseases and treated with antibiotics and vaccine

\section{Ambient temperature and relative humidity}

Indoor climatic conditions (ambient temperature, relative humidity and temperature-humidity index recorded during the experimental period (Figure 1). Temperature Humidity Index (THI) calculated according to Marai et al. (2001). 
Table 1. Chemical analysis of tap water and saline well water under conditions of South Sinai, Egypt

\begin{tabular}{lcc}
\hline Parameters & TW & SW \\
\hline Total dissolved solids $(\mathrm{mg} / \mathrm{l})$ & 265.0 & 3398.0 \\
Electric conductivity $(\mu \mathrm{S} / \mathrm{m})$ & 512.0 & 5540.0 \\
$\mathrm{pH}$ & 6.9 & 7.6 \\
Sodium $(\mathrm{mg} / \mathrm{l})$ & 30.0 & 640.0 \\
Potassium $(\mathrm{mg} / \mathrm{l})$ & 4.0 & 8.0 \\
Calcium $(\mathrm{mg} / \mathrm{l})$ & 46.0 & 302.7 \\
Magnesium $(\mathrm{mg} / \mathrm{l})$ & 10.7 & 160.3 \\
Carbonate $(\mathrm{mg} / \mathrm{l})$ & 0.0 & 15.0 \\
Bicarbonate $(\mathrm{mg} / \mathrm{l})$ & 125.0 & 115.9 \\
Sulphate $(\mathrm{mg} / \mathrm{l})$ & 52.4 & 800.0 \\
Chloride $(\mathrm{mg} / \mathrm{l})$ & 59.1 & 1414.0 \\
\hline
\end{tabular}

TW= tap water (265 ppm total dissolved solids); SW= saline well water (3398 ppm total dissolved solids)

Table 2. Chemical composition of the zeolite (Clinoptilolite) used in the experiment

\begin{tabular}{cc|cc|cc}
\hline Cations & $\%$ & Major elements (oxides) & \% & Other elements & Trace \\
\hline $\mathrm{K}_{2} \mathrm{O}$ & 3.266 & $\mathrm{SiO}_{2}$ & 62.22 & $\mathrm{Cl}$ & 0.025 \\
$\mathrm{CaO}$ & 3.583 & $\mathrm{Al}_{2} \mathrm{O}_{3}$ & 11.096 & $\mathrm{BaO}$ & 0.085 \\
$\mathrm{Na}_{2} \mathrm{O}$ & 0.780 & $\mathrm{Na}_{2} \mathrm{O}$ & 0.780 & $\mathrm{P}_{2} \mathrm{O}_{5}$ & 0.033 \\
& & $\mathrm{MgO}$ & 0.599 & $\mathrm{ZnO}$ & 0.025 \\
& & $\mathrm{CaO}$ & 3.583 & $\mathrm{SrO}$ & 0.047 \\
& $\mathrm{Fe}_{2} \mathrm{O}_{3}$ & 4.033 & $\mathrm{PbO}$ & 0.002 \\
$\mathrm{~K}_{2} \mathrm{O}$ & 3.266 & & \\
$\mathrm{TiO}_{2}$ & 0.339 & & \\
$\mathrm{ZrO}_{2}$ & 0.112 & & \\
\hline
\end{tabular}

Table 3. Composition and calculated analysis of the experimental diets

\begin{tabular}{|c|c|c|c|}
\hline Ingredients & Basal diet & Zeolite (2\%) & Zeolite (4\%) \\
\hline Zeolite & 0.0 & 2.00 & 4.00 \\
\hline Yellow corn & 57.00 & 55.00 & 53.00 \\
\hline Soybean meal (44\% CP) & 29.00 & 29.00 & 29.00 \\
\hline Wheat bran & 2.84 & 2.84 & 2.84 \\
\hline Limestone ground & 7.60 & 7.60 & 7.60 \\
\hline Dicalcium phosphate & 1.50 & 1.50 & 1.50 \\
\hline Vitamins and minerals premix* & 0.40 & 0.40 & 0.40 \\
\hline Oil & 1.30 & 2.00 & 2.80 \\
\hline Salt & 0.30 & 0.30 & 0.30 \\
\hline Dl- methionine & 0.06 & 0.06 & 0.06 \\
\hline Total & 100 & 100 & 100 \\
\hline \multicolumn{4}{|l|}{ Calculated values } \\
\hline Crude protein & 18.05 & 17.88 & 17.71 \\
\hline Crude fiber & 3.32 & 3.32 & 3.32 \\
\hline Ether extract & 2.81 & 2.81 & 2.81 \\
\hline Ash & 2.37 & 2.37 & 2.37 \\
\hline Metabolizable energy $(\mathrm{kcal} / \mathrm{kg})$ & 2763.6 & 2763.2 & 2763.7 \\
\hline Calcium $(\%)$ & 3.31 & 3.31 & 3.31 \\
\hline Available phosphorus (\%) & 0.40 & 0.40 & 0.40 \\
\hline
\end{tabular}

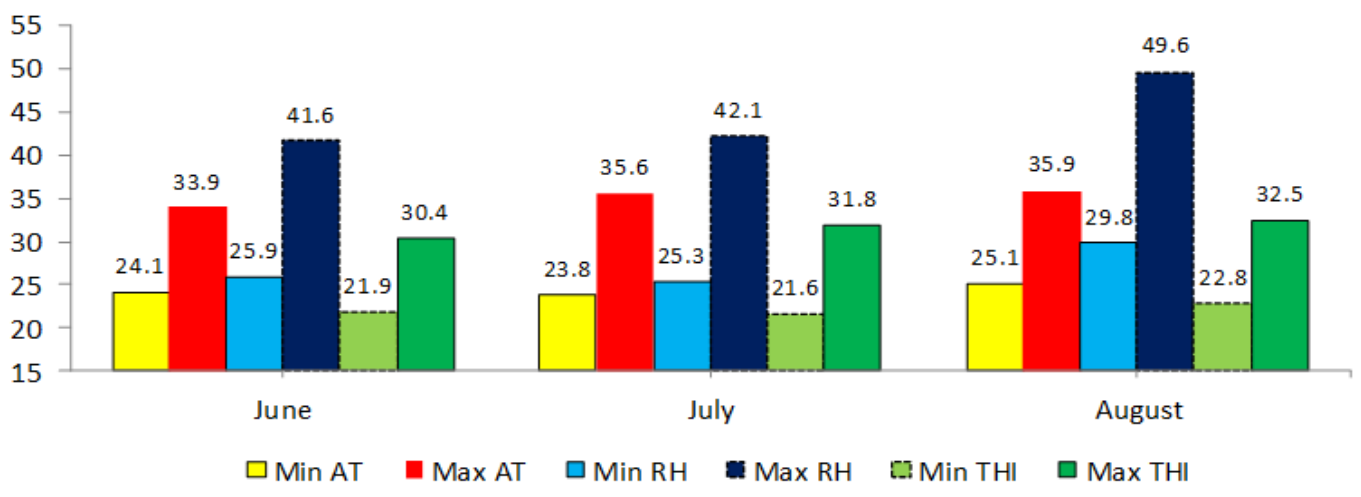

Figure 1. Indoor ambient temperature, relative humidity and temperature-humidity index throughout experimental period. AT $\left({ }^{\circ} \mathrm{C}\right)=$ ambient temperature, $\mathrm{RH}(\%)=$ relative humidity, $\mathrm{THI}=$ temperature-humidity index, $\mathrm{THI}=\mathrm{db}{ }^{\circ} \mathrm{C}-\left[(0.31-0.31 \times \mathrm{RH}) \times\left(\mathrm{db}{ }^{\circ} \mathrm{C}-\right.\right.$ 14.4)]. Where, $\mathrm{db}^{\circ} \mathrm{C}=$ dry bulb temperature in centigrade, The THI values were classified as absence of heat stress $(<27.8)$, moderate heat stress $(27.8$ $28.8)$, severe heat stress $(28.9-29.9)$ and very severe heat stress $(>30.0)$. 


\section{Blood samples and hormonal assay}

Blood samples were monthly collected from wing vein from all hens into two tubes (anticoagulant EDTA treated and non-EDTA tubes). Samples treated with anticoagulant EDTA used for determination of red blood cells (RBC's), Hemoglobin (Hb), Packed Cell Volume (PCV), Mean Corpuscular Volume (MCV), mean corpuscular hemoglobin $(\mathrm{MCH})$ and Mean Corpuscular Hemoglobin Concentration (MCHC) by the coulter (HA-VET, Clinding - Belgium). Plasma was collected by centrifugation for 15 minutes at $3000 \mathrm{rpm}$ and it stored at $-20{ }^{\circ} \mathrm{C}$ until determination of hormones (aldosterone, tri-iodothyronine, progesterone and corticosterone) by ELISA method using commercial kits and blood metabolites (total protein, albumin, glucose, cholesterol, alanine and aspartic transaminase, creatinine and total antioxidant capacity) using commercial kits. Globulin was calculated by the difference between total protein and albumin. Other samples (non-EDTA tubes) used to collected serum by centrifugation for 15 minutes at $3000 \mathrm{rpm}$ and it stored at $-20^{\circ} \mathrm{C}$ until determination blood minerals (calcium, phosphorus, sodium and potassium) by calorimetrically using commercial kits.

\section{Productive performance}

All experimental hens were used to evaluate the productive performance. Body weight was recorded at initial body weight (22 weeks) and at final body weight (34 weeks). Egg number and egg weight were daily recorded for 90 days (egg production period). Egg mass was calculated by multiplying average egg weight by egg number. Feed and water intake were recorded. Feed conversion was calculated as follows: feed conversion=total feed intake/ total egg mass. Mortality rate was daily recorded for each group from one day to end of the experiment.

Thirty eggs were randomly collected from each treatment (180 eggs) to measure egg quality traits according to Stino et al. (1982) and El -Wardany et al. (1994). These traits included that: Egg shape index = egg width/egg length $\times 100$ using Vernier Caliper for measurements. Egg shell weight was recorded by digital balance to nearest 0.1 gram. Shell $(\%)=$ shell weight/egg weight $\times 100$. Egg shell thickness measured with membrane in mm (average of the broad, narrow ends and equator areas of egg). Yolk weight was recorded by digital balance to nearest 0.1 gram. Yolk (\%) $=$ yolk weight $/$ egg weight $\times 100$. Yolk index calculated as yolk height $/$ yolk diameter $\times 100$. Albumen weight was calculated by subtracting yolk and shell weight from total egg weight. Albumen $(\%)=$ albumen weight $/$ egg weight $\times$ 100. Yolk/Albumen ratio = yolk weight $/$ albumen weight $\times 100$.

\section{Statistical analysis}

Data were analyzed by the least square analysis of variance using the General Linear Model Procedure (SAS, 2004) according to following model:

$Y_{i j}=\mu+\operatorname{Tr}_{i}+e_{i j}$

Where, $Y_{i j}=$ observations; $\mu=$ overall mean; $\operatorname{Tr}_{\mathrm{i}}=$ effect of $\mathrm{i}^{\text {th }}$ group (i: 1-6); $\mathrm{e}_{\mathrm{ij}}=$ experimental error.

Duncan's New Multiple Range Test (Duncan, 1955) separated differences among treatment means.

\section{RESULTS AND DISCUSSION}

\section{Hematological parameters}

Red blood cells (RBC's) count and hemoglobin $(\mathrm{Hb})$ concentration were lower $(\mathrm{P}<0.05)$ in the hens of $\mathrm{S}$ (hens drank saline well water) as compared to the hens in the other treatments (Table 4). On the other hand, MCV increased $(\mathrm{P}<0.05)$ in the hens of $\mathrm{S}$ group when compared to the hens of T, T1, T2 treatment groups. Meanwhile, MCHC decreased $(\mathrm{P}<0.05)$ in the hens of $\mathrm{S}$ group as compared to the hens of $\mathrm{T}, \mathrm{T} 1, \mathrm{~T} 2$ and $\mathrm{S} 1$ groups. Nevertheless, no significant differences between the treatment's groups in PCV and MCH was seen. Hematological parameters have been considered important as indicator for the healthy birds, so hens drank saline well water might suffer from drastic physiological changes to preserve the consistence and body stability (Morsy et al., 2012).

These results agree with the results of Morsy et al. (2012); Emam et al. (2017) and Morsy (2018). They reported that the negatively disturbances in hematological parameters as a result of drank saline well water might be due to increased water intake that may be caused hemodilution and increased total body water. In addition, salt intake caused varying degrees of anhydremia resulting in an elevation of specific gravity and hematocrit value in the blood (Amal, 2013). On the other hand, the enhancement in hematological parameters of hens fed 2 and $4 \%$ zeolite (T1, T2, S1 and S2) may suggest that the principal role of zeolite supplemental in reducing the deleterious effects of saline stress by decreased a number of toxic substances such as heavy metal salts, nitrates, nitrites, mycotoxins, radionuclides and metabolism products (Morsy, 2018). Also, zeolites, being ion-exchangers, participate in certain biochemical transformations, normalize the homeostasis of animals and increase the nutrient conversion, so it may be reversible in increase of RBC's and Hb values (Andronikashvili et al., 2009). 
Table 4. Effect of zeolite supplementation on hematological parameters of laying hens drinking saline well water

\begin{tabular}{lccccccc}
\hline Traits & T & T1 & T2 & S & S1 & S2 & \pm SE \\
\hline RBC's $\left(\times 10^{6} / \mathrm{mm}^{3}\right)$ & $2.97^{\mathrm{a}}$ & $3.15^{\mathrm{a}}$ & $3.11^{\mathrm{a}}$ & $2.60^{\mathrm{b}}$ & $2.90^{\mathrm{ab}}$ & $2.96^{\mathrm{a}}$ & 0.14 \\
$\mathrm{Hb}(\mathrm{g} / \mathrm{dl})$ & $11.83^{\mathrm{a}}$ & $12.17^{\mathrm{a}}$ & $12.63^{\mathrm{a}}$ & $10.73^{\mathrm{b}}$ & $11.96^{\mathrm{a}}$ & $11.63^{\mathrm{ab}}$ & 0.61 \\
PCV (\%) & 33.29 & 34.43 & 35.35 & 33.08 & 34.17 & 34.80 & 1.89 \\
MCV (fl) & $111.40^{\mathrm{b}}$ & $110.21^{\mathrm{b}}$ & $111.74^{\mathrm{b}}$ & $130.03^{\mathrm{a}}$ & $118.29^{\mathrm{ab}}$ & $118.08^{\mathrm{ab}}$ & 6.00 \\
MCH (pg) & 39.67 & 38.99 & 39.96 & 41.99 & 41.25 & 39.46 & 1.54 \\
MCHC (\%) & $35.61^{\mathrm{a}}$ & $35.35^{\mathrm{a}}$ & $35.76^{\mathrm{a}}$ & $32.77^{\mathrm{b}}$ & $35.14^{\mathrm{a}}$ & $33.65^{\mathrm{ab}}$ & 0.79 \\
\hline
\end{tabular}

$\mathrm{T}=$ hens drank tap water (265 ppm total dissolved solids) and fed basal diet, $\mathrm{T} 1=$ hens drank tap water and fed diet containing $2 \%$ zeolite, $\mathrm{T} 2=$ hens drank tap water and fed diet containing $4 \%$ zeolite, $\mathrm{S}=$ hens drank saline well water (3398 ppm total dissolved solids) and fed basal diet, $\mathrm{S} 1=$ hens drank saline well water and fed diet containing $2 \%$ zeolite, $\mathrm{S} 2=$ hens drank saline well water and fed diet containing $4 \%$ zeolite, $\pm \mathrm{SE}=$ standard error, $\mathrm{RBC}$ 's $=$ red blood cells, $\mathrm{Hb}=$ hemoglobin, $\mathrm{PCV}=$ packed cell volume, $\mathrm{MCV}=$ mean corpuscular volume, $\mathrm{MCH}=$ mean corpuscular hemoglobin, $\mathrm{MCHC}=$ mean corpuscular hemoglobin concentration, ${ }^{\mathrm{a}, \mathrm{b}}$ Means bearing different superscripts within the same row are significantly different $(\mathrm{P}<0.05)$.

\section{Metabolites}

Hens drank saline well water ( $\mathrm{S}$ group) showed decrease $(\mathrm{P}<0.05)$ in total protein, globulin and glucose concentrations by $25.07,57.87$ and $11.95 \%$, respectively as compared to the hens drank tap water ( $\mathrm{T}$ group) and by $26.65,57.08$ and $14.26 \%$, respectively as compared to the hens of T2 which drank tap water $+4 \%$ zeolite (Table 5).

These results revealed that the decrease in some metabolites might be due to the effect of salt stress. Drinking saline well water might reduce hepatic synthesis of RNA, which in turn depressed the incorporation of amino acids for protein synthesis (Tata and Widnell, 1966). Also, the depression in total protein could be considered as a physiological accommodation to prevent excessive passage of fluids into the interstitial tissue due to the level of salinity (Abdel Samee and El-Masry, 1992; Amal, 2013; Emam et al., 2017). Meanwhile, it's worthy to reveal that biochemical parameters values of zeolite groups had analogous with control group. Valpotic et al. (2016) reported that zeolite improved the absorption of immunoglobulins, total proteins and some microelements, especially iron and copper in cow and cocks (Ipek et al., 2012 and Morsy, 2018). Moreover, Macháček et al. (2010) demonstrated that differences in glucose and total protein as a result of zeolite (clinoptilolite) administration in feed of laying hen (at level of $2 \%$ and $4 \%$ ) were not significantly effective as compared to control ones and remained at the range of reference values (Lotfollahian et al., 2004; Eleroglu et al., 2011 and Safaeikatouli et al., 2011). Also, Nik-Khan (2002) reported that useing $1 \mathrm{~g}$ zeolite/ kg body weight/ daily had the positive effects on increasing serum immunoglobulins.

The decrease in glucose level could be interpreted as a consequence of the increased transport of glucose and salt through membranes into tissue cells (Karadjole et al., 1999). However, drank saline well water led to expose the body to a metabolic stress and elevation in energy requirements to maintain the sodium/potassium gradient and hence decreased concentration of blood glucose (Guyton and Hall, 2006; Amal, 2013; Morsy, 2018). However, cholesterol concentration significantly decreased in the hens of $\mathrm{S}$ group as compared to the hens of other treatments. These results agree with the results of Miles and Henry (2007); Safaeikatouli et al. (2011); Amal (2013) and Morsy (2018) that confirmed protein and fat metabolism were negatively affected as a result of drinking saline water and additional of zeolite in diets but did not have adverse effects on cholesterol concentration. On the other hand, no significant effect was observed among treatments on albumin concentration. Hens drank saline well water obtained decrease $(\mathrm{P}<0.05)$ in total antioxidant capacity (TAC) concentrations $(44.87 \%)$ as compared to the hens that drank tap water $(37.68 \%)$ and the hens of T2. However, hens of S1 and S2 groups showed insignificant increment in TAC as compared to the hens of S group (Figure 2).

Table 5. Effect of zeolite supplementation on biochemical parameters of laying hens drinking saline well water

\begin{tabular}{|c|c|c|c|c|c|c|c|}
\hline Traits & $\mathbf{T}$ & T1 & $\mathbf{T} 2$ & $\mathbf{S}$ & S1 & S2 & $\pm \mathrm{SE}$ \\
\hline Total protein $(\mathrm{g} / \mathrm{dl})$ & $6.50^{\mathrm{a}}$ & $5.67^{\mathrm{ab}}$ & $6.64^{\mathrm{a}}$ & $4.87^{\mathrm{b}}$ & $5.70^{\mathrm{ab}}$ & $6.08^{\mathrm{ab}}$ & 0.39 \\
\hline Albumin (g/dl) & 3.76 & 3.19 & 3.96 & 3.72 & 3.44 & 3.94 & 0.24 \\
\hline Globulin (g/dl) & $2.73^{\mathrm{a}}$ & $2.48^{\mathrm{ab}}$ & $2.68^{\mathrm{a}}$ & $1.15^{\mathrm{b}}$ & $2.25^{\mathrm{ab}}$ & $2.14^{\mathrm{ab}}$ & 0.39 \\
\hline Glucose $(\mathrm{g} / \mathrm{dl})$ & $267.26^{\mathrm{a}}$ & $260.66^{\mathrm{a}}$ & $274.47^{\mathrm{a}}$ & $235.32^{\mathrm{b}}$ & $254.14^{\mathrm{ab}}$ & $255.81^{\mathrm{ab}}$ & 10.30 \\
\hline Cholesterol (g/dl) & $75.07^{\mathrm{a}}$ & $81.04^{\mathrm{a}}$ & $83.20^{\mathrm{a}}$ & $58.01^{\mathrm{b}}$ & $72.79^{\mathrm{a}}$ & $78.92^{\mathrm{a}}$ & 5.93 \\
\hline
\end{tabular}

$\mathrm{T}=$ hens drank tap water (265 ppm total dissolved solids) and fed basal diet, T1 = hens drank tap water and fed diet containing $2 \%$ zeolite, T2 = hens drank tap water and fed diet containing $4 \%$ zeolite, $\mathrm{S}=$ hens drank saline well water $(3398$ ppm total dissolved solids $)$ and fed basal diet, $\mathrm{S} 1=$ hens drank saline well water and fed diet containing $2 \%$ zeolite, $\mathrm{S} 2=$ hens drank saline well water and fed diet containing $4 \%$ zeolite, \pm SE $=$ standard error, ${ }^{\mathrm{a}, \mathrm{b}}$ Means bearing different superscripts within the same row are significantly different $(\mathrm{P}<0.05)$. 


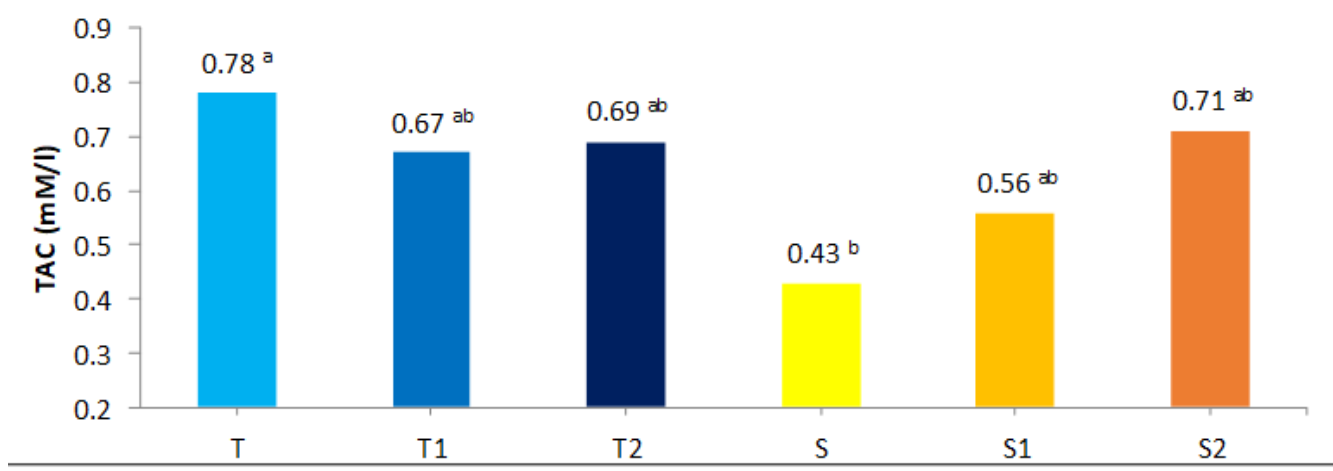

Figure 2. Effect of zeolite supplementation on total antioxidant capacity of laying hens drinking saline well water $\mathrm{T}=$ hens drank tap water ( $265 \mathrm{ppm}$ total dissolved solids) and fed basal diet, $\mathrm{T} 1=$ hens drank tap water and fed diet containing $2 \%$ zeolite, $\mathrm{T} 2=$ hens drank tap water and fed diet containing $4 \%$ zeolite, $\mathrm{S}=$ hens drank saline well water (3398 ppm total dissolved solids) and fed basal diet, $\mathrm{S} 1=$ hens drank saline well water and fed diet containing $2 \%$ zeolite, $\mathrm{S} 2=$ hens drank saline well water and fed diet containing $4 \%$ zeolite, TAC= total antioxidant capacity, ${ }^{\mathrm{a}, \mathrm{b}}$ Means bearing different superscripts are significantly different $(\mathrm{P}<0.05)$.

\section{Liver and kidney functions}

Alanine transaminase (ALT) and aspartic transaminase (AST) were increased $(\mathrm{P}<0.05)$ in the hens of $\mathrm{S}$ (hens drank saline well water) as compared to the hens in other treatments. Meanwhile, creatinine level significantly increased in the hens of $\mathrm{S}$ as compared to the hens of T, T2, T2 and S1. However, ALT was increased $(\mathrm{P}<0.05)$ in the hens of S1 and S2 as compared to the hens of T, T1 and T2. However, no significant differences between the hens drank saline well water plus zeolite (S1 and S2) and the hens drank tap water only (T) or drank tap water plus zeolite (T1 and T2) in AST and creatinine concentrations (Table 6). These results indicating that increased salt load might cause harmful effects on the liver and kidney functions and in turn the animals health (Amal, 2013 and Morsy et al., 2012 and 2016 and Morsy, 2018). On the other hand, zeolite (Clinoptiolite) might be reduced lipid peroxidation and normalized the liver functions in the animals drinking saline water and/or may be safe supplements even though more histological studies are needed to prove it (Tukmechi et al., 2011; Sheikhzadeh et al., 2017; Morsy, 2018).

Table 6. Effect of zeolite supplementation on liver and kidney functions parameters of laying hens drinking saline well water

\begin{tabular}{|c|c|c|c|c|c|c|c|}
\hline Traits & $\mathbf{T}$ & T1 & $\mathbf{T 2}$ & $\mathbf{S}$ & S1 & S2 & $\pm \mathrm{SE}$ \\
\hline ALT (i.u./l) & $38.23^{\mathrm{c}}$ & $40.31^{\mathrm{c}}$ & $39.60^{c}$ & $67.96^{\mathrm{a}}$ & $53.62^{\mathrm{b}}$ & $55.23^{\mathrm{b}}$ & 1.49 \\
\hline $\operatorname{AST}(i . u / l)$ & $82.75^{\mathrm{b}}$ & $84.85^{\mathrm{b}}$ & $88.18^{\mathrm{b}}$ & $97.80^{\mathrm{a}}$ & $88.79^{\mathrm{b}}$ & $83.56^{\mathrm{b}}$ & 2.60 \\
\hline Creatinine $(\mathrm{mg} / \mathrm{dl})$ & $0.41^{\mathrm{b}}$ & $0.39^{\mathrm{b}}$ & $0.35^{\mathrm{b}}$ & $0.60^{\mathrm{a}}$ & $0.39^{\mathrm{b}}$ & $0.44^{\mathrm{ab}}$ & 0.09 \\
\hline
\end{tabular}

$\mathrm{T}=$ hens drank tap water (265 ppm total dissolved solids) and fed basal diet, $\mathrm{T} 1=$ hens drank tap water and fed diet containing $2 \%$ zeolite, T2 = hens drank tap water and fed diet containing $4 \%$ zeolite, $\mathrm{S}=$ hens drank saline well water ( $3398 \mathrm{ppm}$ total dissolved solids) and fed basal diet, $\mathrm{S} 1=$ hens drank saline well water and fed diet containing $2 \%$ zeolite, S2 $=$ hens drank saline well water and fed diet containing $4 \%$ zeolite, $\pm \mathrm{SE}=$ standard error, ALT $=$ alanine transaminase, AST $=$ aspartic transaminase, ${ }^{\mathrm{a}, \mathrm{b}}$ Means bearing different superscripts within the same row are significantly different $(\mathrm{P}<0.05)$.

\section{Mineral parameters}

Hens of drank saline well water had higher $(\mathrm{P}<0.05)$ calcium, sodium, sodium/potassium ratio and sodium/ (sodium + potassium) index concentrations by 35.79, 15.29, 69.20 and $1.02 \%$, respectively as compared to the hens drank tap water. Meanwhile, no significant differences between the hens S1 and S2 groups and the hens of T, T1 and T2 groups in calcium, sodium, sodium/potassium ratio and sodium/ (sodium + potassium) index was seen (Table 7).

In contrary trend, potassium level decreased $(\mathrm{P}<0.05)$ in the hens of $\mathrm{S}$ group as compared with the hens of other treatments. However, no significant differences between the hens of S1 and S2 groups and the hens of T, T1 and T2 groups in potassium level was seen. Minerals in body fluids and tissues as electrolytes, alarmed with the maintenance of osmotic pressure, acid-base balance, membrane permeability and tissue irritability (Milne, 1996; Underwood and Suttle, 1999). So, the higher levels of electrolytes might be explained as hens drank saline well water (Table 1) containing higher concentration of these minerals as compared to the hens drank tap water and it appears quite logical that the high level of electrolytes in drinking water entailed the increased levels in the serum (Karadjole et al., 1999; Morsy et al., 2012; Amal, 2013; Morsy, 2018). In addition, increased calcium level in the hens of T3 group might resulted in increasing rate of its reabsorption and so, its blood level with insignificantly decreased phosphorus level due to the reciprocal reverse relationship as increased blood calcium level resulted in increasing parathyroid hormone secretion which inhibits the reabsorption of phosphorus in renal tubules (Morsy et al., 2012 and Amal, 2013). Indeed, the negative relationship between serum sodium and potassium levels might protect the body against hyperkalemia and muscle irritability (Ahmed and Abdel-Rahman, 2004; Abbas et al., 2008; Morsy et al., 2012 and 2016 and Amal, 2013). Likewise, the increase in the sodium/potassium ratio and sodium/(sodium+potassium) index in the hens of T3 group might be due to increase the rate of glomerular filtration in the kidney for such electrolytes due to the drinking saline 
well water and thus a direct increase in the blood (Amal, 2003; Morsy et al., 2012; Amal, 2013; Morsy, 2018). On the other hand, the results of blood mineral parameters indicated no significant differences among the hens drank saline well water and received zeolite (S1 and S2 groups) obtaing that zeolite might be being ion-exchangers, participates in certain biochemical transformations, including the transport, activation and prolongation of enzyme and hormone action, maintain ion balance in terms of electrolyte system and normalize the homeostasis of hens (Andronikashvili et al., 2009; Colella, 2011). Roland et al. (1985) hypothesized that the beneficial effect of zeolite on bone quality may be related to its high affinity for calcium and phosphorus and its ion-exchange capability. These results agree with the results of Frost et al. (1992); Ward et al. (1993) and Eleroglu et al. (2011) that reported zeolite have a positively effect on the balance of serum calcium and phosphorus levels and regulate electrolyte balance in birds.

Table 7. Effect of zeolite supplementation on blood minerals of laying hens drinking saline well water

\begin{tabular}{|c|c|c|c|c|c|c|c|}
\hline Traits & $\mathbf{T}$ & T1 & $\mathbf{T 2}$ & $\mathbf{S}$ & S1 & S2 & $\pm \mathrm{SE}$ \\
\hline $\mathrm{Ca}(\mathrm{mg} / \mathrm{dl})$ & $9.61^{b}$ & $9.26^{\mathrm{b}}$ & $10.46^{\text {ab }}$ & $13.05^{\mathrm{a}}$ & $10.09^{\mathrm{ab}}$ & $9.63^{b}$ & 0.98 \\
\hline $\mathrm{P}(\mathrm{mg} / \mathrm{dl})$ & 3.27 & 3.39 & 3.22 & 3.10 & 3.28 & 3.31 & 0.13 \\
\hline $\mathrm{Na}(\mathrm{mmol} / \mathrm{l})$ & $151.13^{\mathrm{b}}$ & $144.54^{\mathrm{b}}$ & $142.10^{\mathrm{b}}$ & $174.24^{\mathrm{a}}$ & $139.66^{\mathrm{b}}$ & $135.90^{\mathrm{b}}$ & 5.49 \\
\hline $\mathrm{K}(\mathrm{mmol} / \mathrm{l})$ & $4.05^{\mathrm{a}}$ & $4.57^{\mathrm{a}}$ & $4.47^{\mathrm{a}}$ & $2.76^{\mathrm{b}}$ & $4.18^{\mathrm{a}}$ & $4.22^{\mathrm{a}}$ & 0.44 \\
\hline $\mathrm{Na} / \mathrm{K}$ ratio & $37.31^{\mathrm{b}}$ & $31.62^{\mathrm{b}}$ & $31.79^{\mathrm{b}}$ & $63.13^{\mathrm{a}}$ & $33.41^{\mathrm{b}}$ & $32.20^{\mathrm{b}}$ & 7.01 \\
\hline $\mathrm{Na} /(\mathrm{Na}+\mathrm{K})$ index & $0.974^{\mathrm{b}}$ & $0.969^{b}$ & $0.969^{\mathrm{b}}$ & $0.984^{\mathrm{a}}$ & $0.971^{\mathrm{b}}$ & $0.970^{\mathrm{b}}$ & 0.002 \\
\hline
\end{tabular}

$\mathrm{T}=$ hens drank tap water (265 ppm total dissolved solids) and fed basal diet, T1 = hens drank tap water and fed diet containing $2 \%$ zeolite, T2 = hens drank tap water and fed diet containing $4 \%$ zeolite, $\mathrm{S}=$ hens drank saline well water (3398 ppm total dissolved solids) and fed basal diet, $\mathrm{S} 1=$ hens drank saline well water and fed diet containing $2 \%$ zeolite, $\mathrm{S} 2=$ hens drank saline well water and fed diet containing $4 \%$ zeolite, \pm SE $=$ standard error, $\mathrm{Ca}=$ calcium, $\mathrm{P}=$ phosphorus, $\mathrm{Na}=$ sodium, $\mathrm{K}=$ potassium, ${ }^{\mathrm{a}, \mathrm{b}}$ Means bearing different superscripts within the same row are significantly different $(\mathrm{P}<0.05)$.

\section{Hormonal parameters}

Figure 3 showed that aldosterone hormone significantly decreased $(\mathrm{P}<0.05)$ in the hens of $\mathrm{S}$ group by $23.16,24.57$ and $21.26 \%$ as compared to the T, T1 and T2 groups, respectively. Meanwhile, no significant differences were observed among the hens of S1, S2, T2, T1 and T groups. This decreased in aldosterone hormone in the hens of S group could be owing to the physiological effects of salt stress retention and excretion by reducing the plasma aldosterone concentration in nearly $50 \%$ of control values (Amal, 2003 and Morsy, 2018). On the other hand, no significant differences among treatments were observed in tri-iodothyronine and progesterone hormones (Figures 4 and 5). However, progesterone hormone was insignificantly lower in the hens of $\mathrm{S}$ group when compared to the other treatments.

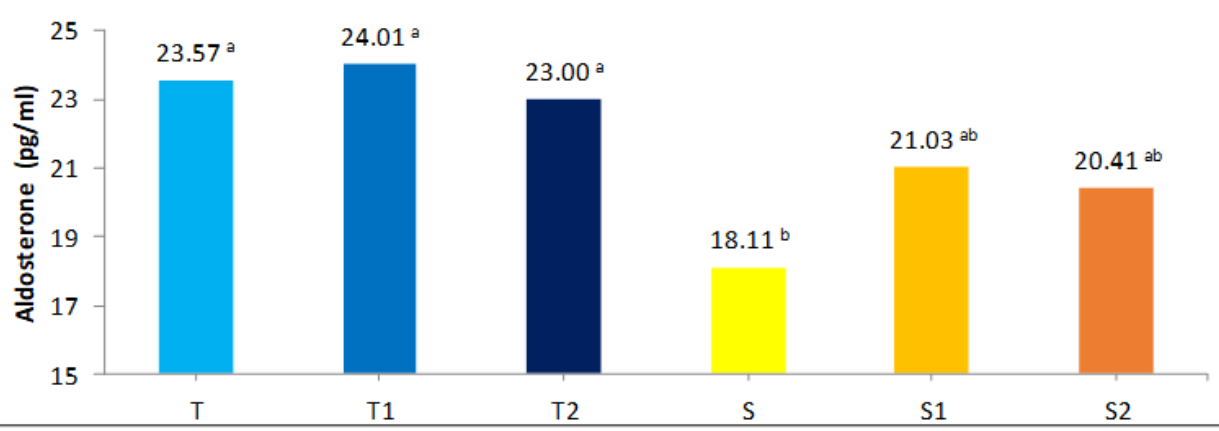

Figure 3. Effect of zeolite supplementation on aldosterone hormone of laying hens drinking saline well water. $\mathrm{T}=\mathrm{hens}$ drank tap water (265 ppm total dissolved solids) and fed basal diet, $\mathrm{T} 1=$ hens drank tap water and fed diet containing $2 \%$ zeolite, T2= hens drank tap water and fed diet containing $4 \%$ zeolite, $\mathrm{S}=$ hens drank saline well water (3398 ppm total dissolved solids) and fed basal diet, $\mathrm{S} 1=$ hens drank saline well water and fed diet containing $2 \%$ zeolite, $\mathrm{S} 2=$ hens drank saline well water and fed diet containing $4 \%$ zeolite, ${ }^{\mathrm{a}, \mathrm{b}}$ Means bearing different superscripts are significantly different $(\mathrm{P}<0.05)$.

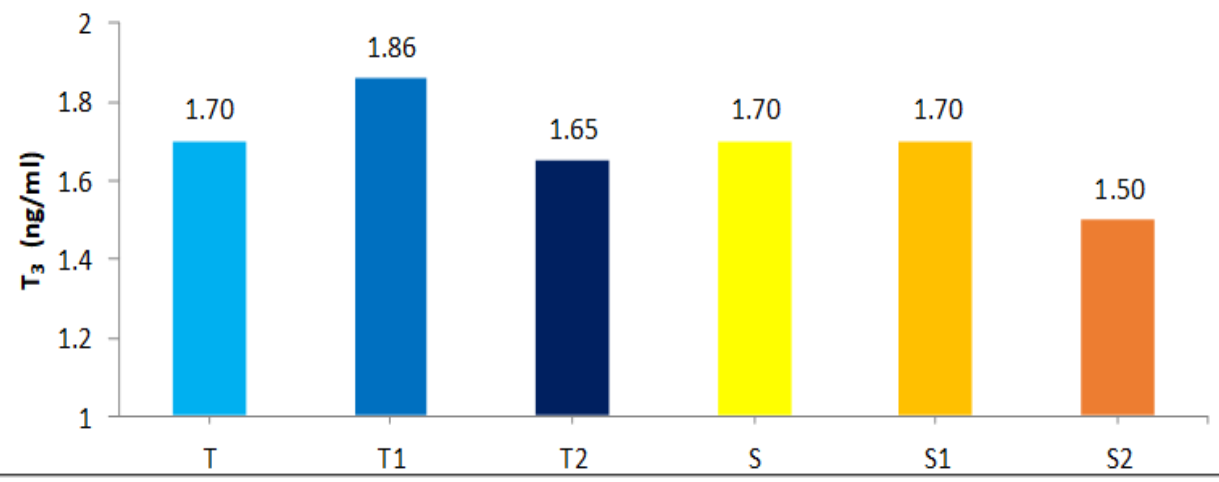

Figure 4. Effect of zeolite supplementation on tri-iodothyronine hormone of laying hens drinking saline well water $\mathrm{T}=$ hens drank tap water (265 ppm total dissolved solids) and fed basal diet, $\mathrm{T} 1=$ hens drank tap water and fed diet containing $2 \%$ zeolite, $\mathrm{T} 2=$ hens drank tap water and fed diet containing $4 \%$ zeolite, $\mathrm{S}=$ hens drank saline well water (3398 ppm total dissolved solids) and fed basal diet, $\mathrm{S} 1=$ hens drank saline well water and fed diet containing $2 \%$ zeolite, $\mathrm{S} 2=$ hens drank saline well water and fed diet containing $4 \%$ zeolite, $\mathrm{T}_{3}=$ triiodothyronine hormone 


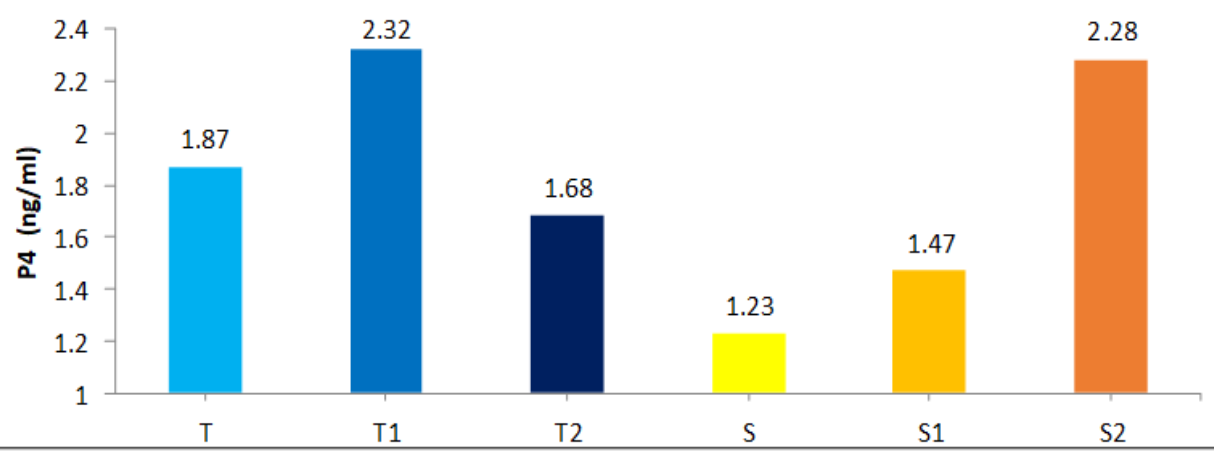

Figure 5. Effect of zeolite supplementation on progesterone hormone of laying hens drinking saline well water $\mathrm{T}=$ hens drank tap water (265 ppm total dissolved solids) and fed basal diet, $\mathrm{T} 1=$ hens drank tap water and fed diet containing $2 \%$ zeolite, $\mathrm{T} 2=$ hens drank tap water and fed diet containing $4 \%$ zeolite, $\mathrm{S}=$ hens drank saline well water (3398 ppm total dissolved solids) and fed basal diet, $\mathrm{S} 1=$ hens drank saline well water and fed diet containing $2 \%$ zeolite, $\mathrm{S} 2=$ hens drank saline well water and fed diet containing $4 \%$ zeolite, $\mathrm{P}_{4}=$ progesterone hormone.

\section{Body weight}

The Final Body Weight (FBW) and Body Weight Changes (BWC) were insignificantly increased in the hens of S group as compared to the hens in T, T1 and T2 groups, respectively (Table 8). However, hens of S2 group showed insignificantly increased in FBW and BWC when compared to the hens in other treatments. This increase in final body weight and body weight changes might correlated to increase water intake in the hens of S, S1 and S2 groups. Olver (1989) reported no significant dietary effects between treatments which were observed with respect to body weight.

Table 8. Effect of zeolite supplementation on body weight of laying hens drinking saline well water

\begin{tabular}{|c|c|c|c|c|c|c|c|}
\hline Traits & $\mathbf{T}$ & T1 & T2 & $\mathbf{S}$ & S1 & $\mathbf{S 2}$ & $\pm \mathrm{SE}$ \\
\hline IBW (g) & 1629.53 & 1629.26 & 1629.93 & 1629.76 & 1630.76 & 1629.14 & 61.40 \\
\hline FBW (g) & 1919.23 & 1939.60 & 1956.92 & 1970.91 & 1995.33 & 2014.35 & 77.55 \\
\hline BWC (g) & 289.69 & 310.33 & 301.28 & 341.41 & 337.83 & 385.21 & 55.07 \\
\hline
\end{tabular}

$\mathrm{T}=$ hens drank tap water (265 ppm total dissolved solids) and fed basal diet, T1 = hens drank tap water and fed diet containing $2 \%$ zeolite, T2 = hens drank tap water and fed diet containing $4 \%$ zeolite, $\mathrm{S}=$ hens drank saline well water (3398 ppm total dissolved solids) and fed basal diet, $\mathrm{S} 1=$ hens drank saline well water and fed diet containing $2 \%$ zeolite, $\mathrm{S} 2=$ hens drank saline well water and fed diet containing $4 \%$ zeolite, \pm SE $=$ standard error, IBW = initial body weight, FBW = final body weight, $\mathrm{BWC}=$ body weight change.

\section{Productive performance}

Table 9 showed that there was significant $(\mathrm{P}<0.05)$ increases in the value of egg weight in the hens of $\mathrm{S} 2$ group as compared to the hens in $\mathrm{T}$ and $\mathrm{S}$ groups. On the other hand, egg number and egg mass increased $(\mathrm{P}<0.05)$ in the hens of $\mathrm{T} 1, \mathrm{~T} 2$ and $\mathrm{S} 2$ groups as compared to the hens of T, S and S1 groups. However, no significant differences were observed among treatments in feed intake. These results agree with the results of Miazzo et al. (2005) and Salari et al. (2006). These results declared that the hens of T1, T2 and S2 groups had significantly improvement values in feed conversion by $25.05,24.84$ and $25.25 \%$, respectively as compared to the hens of S group hens drank saline well water. On the other hand, no significant differences among the hens of S1, S2, T2, T1 and S groups in feed conversion was seen.

Moreover, water intake was significantly increased in the hens of S and S2 groups when compared to the hens of T, T1 and T2 groups (Figure 6). There has been little attempt to measure whether zeolite has any effect on water intake (Emam et al. 2019). Mumpton and Fishman (1977) reported that water intake was reduced when zeolite was included in the diet of broiler chickens. Many authors described the adverse effect of drinking saline well water on productive performance (Ahmed and Abdel-Rahman, 2004; Morsy et al., 2012). Drinking saline well water might increase the need for water used in the excretion of the most anions and cations through increasing water output and so, the hens increases its water intake (Ahmed and Abdel-Rahman, 2004) and/or the increase in water intake depends on kidney function; the concentration ability of kidney determines the increase in water intake that is necessary to excrete any added salt (Potter, 1968). On the other hand, delayed feed conversion in the hens of S (drank saline well water) group may be attributed to its lowest egg mass as compared to that of other groups.

Improvement in productive performance may attribute to zeolites (clinoptilolite) supplementation by having a number of beneficial effects they provide including better utilization of feed nutrients and positive effects on intestinal microflora and the mechanism of digestion and protection of animals against harmful effects of mycotoxins, stimulation of liver detoxification processes, elimination of heavy metals and radioactive elements (Macháček et al., 2010). Because of their properties, in-feed zeolites participate in many biochemical processes including high cation exchange capacity, adsorption, catalysis and dehydration-rehydration (Macháček et al., 2010). These results agree with the results of Tserveni-Gousi et al. (1997); Nys (1999) and Fendri (2012) that reported the inclusion of zeolites in animal diets improved weight gains and feed conversion, egg production and egg shell quality in laying hens, and had a positive 
effect on egg weight and the physical properties. In addition, positive significant dietary effects of clinoptilolite feeding were noticed with the number of eggs laid per hen, egg weight, shell thickness and efficiency of feed utilization (Miles et al., 1986; Olver, 1989; Fethiere et al., 1990; Roland et al., 1991).

Mortality rate during the experiment increased $(\mathrm{P}<0.05)$ in the hens drinking saline well water when compared to the hens in T1, T2 and S2 groups (Figure 7). However, no significant differences among the hens of S1, S2 and T groups was seen. There were positive effects of zeolite on decreased mortality rate in hens and enhancing prevention of some diseases and improving the health status by reduced colony counts in the gut microflora of the proximal and distal gut and described reduced mortality in broilers and layers (Olver, 1983 and Papaioannou et al., 2005). Indeed, zeolites are used as effective adsorbents of toxic agents, particularly aflatoxins from the feeds (Parlat et al., 1999; Phillips, 1999; Ortatatli and Oguz, 2001; Rizzi et al., 2003). However, they indicated that zeolites may have other effects when included in animal diets (Desheng et al., 2005). Similarly, Pavelic et al. (2002) and Ipek et al. (2012) reported that reactive oxygen species concentration decreased in the liver of mice fed zeolite supplementation as antioxidant. This reducing effect might be associated with adhesion-adsorption, ion-exchange and cation binding properties of clinoptilolite.

Table 9. Effect of zeolite supplementation on productive performance of laying hens drinking saline well water

\begin{tabular}{lccccccc}
\hline Traits & T & T1 & T2 & S & S1 & S2 & \pm SE \\
\hline Egg weight $(\mathrm{g})$ & $44.16^{\mathrm{b}}$ & $46.41^{\mathrm{ab}}$ & $46.53^{\mathrm{ab}}$ & $43.52^{\mathrm{b}}$ & $45.51^{\mathrm{ab}}$ & $47.82^{\mathrm{a}}$ & 1.08 \\
Egg number & $54.80^{\mathrm{b}}$ & $60.59^{\mathrm{a}}$ & $63.53^{\mathrm{a}}$ & $52.67^{\mathrm{b}}$ & $55.45^{\mathrm{b}}$ & $60.37^{\mathrm{a}}$ & 1.34 \\
DFE $(\mathrm{g})$ & 106.41 & 105.39 & 110.88 & 114.50 & 106.23 & 107.78 & 5.49 \\
TFE $(\mathrm{kg})$ & 10.64 & 10.53 & 11.08 & 11.45 & 10.62 & 10.77 & 0.54 \\
Egg mass $(\mathrm{g})$ & $2415.22^{\mathrm{b}}$ & $2811.98^{\mathrm{a}}$ & $2956.05^{\mathrm{a}}$ & $2291.49^{\mathrm{b}}$ & $2523.52^{\mathrm{b}}$ & $2886.89^{\mathrm{a}}$ & 83.00 \\
Feed conversion & $4.40^{\mathrm{ab}}$ & $3.74^{\mathrm{b}}$ & $3.75^{\mathrm{b}}$ & $4.99^{\mathrm{a}}$ & $4.20^{\mathrm{ab}}$ & $3.73^{\mathrm{b}}$ & 0.26 \\
\hline
\end{tabular}

$\mathrm{T}=$ hens drank tap water (265 ppm total dissolved solids) and fed basal diet, $\mathrm{T} 1=$ hens drank tap water and fed diet containing $2 \%$ zeolite, $\mathrm{T} 2=\mathrm{hens}$ drank tap water and fed diet containing $4 \%$ zeolite, $\mathrm{S}=$ hens drank saline well water (3398 ppm total dissolved solids) and fed basal diet, $\mathrm{S} 1=$ hens drank saline well water and fed diet containing $2 \%$ zeolite, S2 = hens drank saline well water and fed diet containing $4 \%$ zeolite, \pm SE $=$ standard error, $\mathrm{DFE}=$ daily feed intake, TFE = total feed intake, ${ }^{\text {a, b, c }}$ Means bearing different superscripts within the same row are significantly different $(\mathrm{P}<$ $0.05)$.

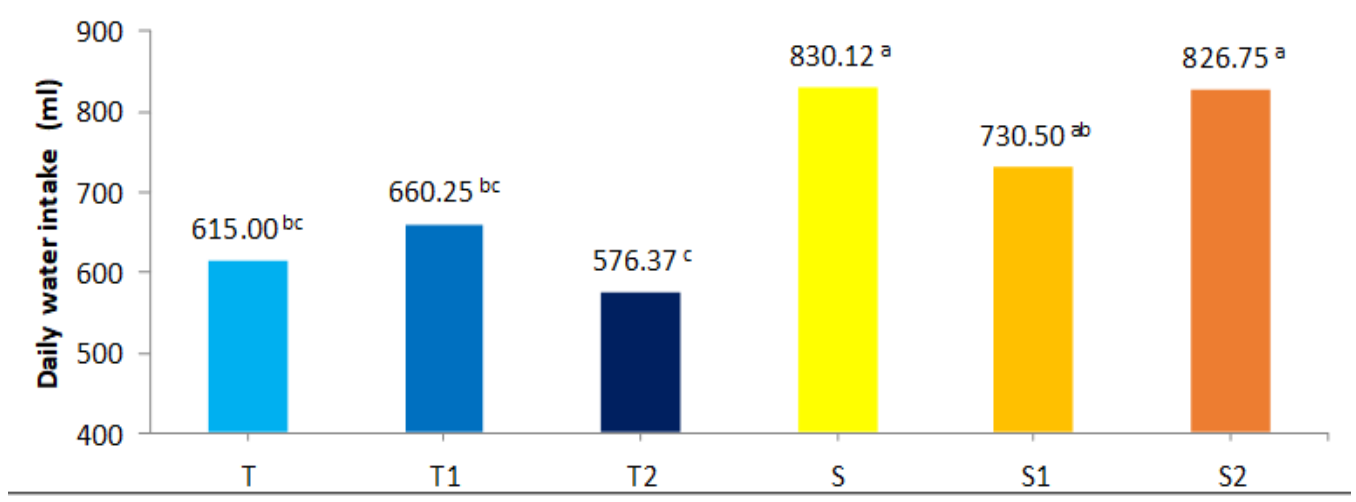

Figure 6. Effect of zeolite supplementation on daily water intake of laying hens drinking saline well water

$\mathrm{T}=$ hens drank tap water ( $265 \mathrm{ppm}$ total dissolved solids) and fed basal diet, $\mathrm{T} 1=$ hens drank tap water and fed diet containing $2 \%$ zeolite, $\mathrm{T} 2=$ hens drank tap water and fed diet containing $4 \%$ zeolite, $\mathrm{S}=$ hens drank saline well water (3398 ppm total dissolved solids) and fed basal diet, $\mathrm{S} 1=$ hens drank saline well water and fed diet containing $2 \%$ zeolite, $S 2=$ hens drank saline well water and fed diet containing $4 \%$ zeolite, ${ }^{a, b, c}$ Means bearing different superscripts are significantly different $(\mathrm{P}<0.05)$.

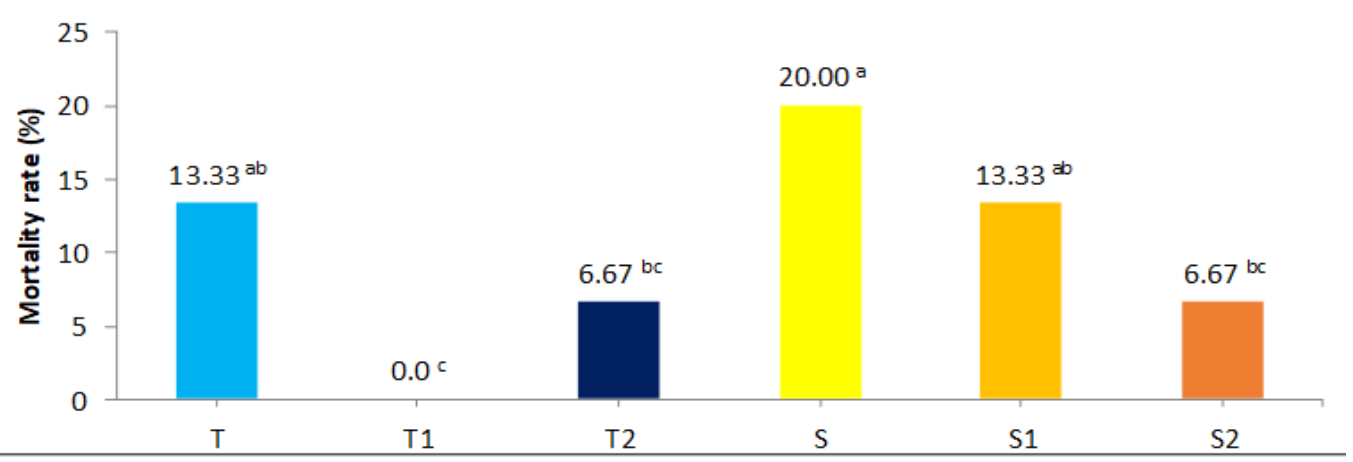

Figure 7. Effect of zeolite supplementation on mortality rate of laying hens drinking saline well water

$\mathrm{T}=$ hens drank tap water (265 ppm total dissolved solids) and fed basal diet, $\mathrm{T} 1=$ hens drank tap water and fed diet containing $2 \%$ zeolite, $\mathrm{T} 2=$ hens drank tap water and fed diet containing $4 \%$ zeolite, $\mathrm{S}=$ hens drank saline well water (3398 ppm total dissolved solids) and fed basal diet, $\mathrm{S} 1=$ hens drank saline well water and fed diet containing $2 \%$ zeolite, S2= hens drank saline well water and fed diet containing $4 \%$ zeolite, ${ }^{\mathrm{a}, \mathrm{b}, \mathrm{c}}$ Means bearing different superscripts are significantly different $(\mathrm{P}<0.05)$. 


\section{Egg quality}

Hens drank saline well water had decreased $(\mathrm{P}<0.05)$ in shell thickness by $6.50,11.61,6.28,7.39$ and $12.01 \%$ as compared to the hens of T, T1, T2, S1 and S2 groups, respectively. However, hens of T, T1, T2, S1 and S2 groups caused insignificantly differences in shell thickness (Figure 8). On the other hand, shell weight increased $(\mathrm{P}<0.05)$ in the hens of S2 group as compared to the hens in T, T2, S and S1 groups. Moreover, shell (\%) was significantly increased in the hens of S2 when compared to the hens of S. Also, albumen weight was significantly increased in the hens of T1 and $\mathrm{S} 2$ when compared to the hens of $\mathrm{T}$ and $\mathrm{S}$ (Table 10). However, yolk weight was increased $(\mathrm{P}<0.05)$ in the hens of $\mathrm{S} 2$ as compared to the hens in drank tap water $(\mathrm{T})$.

Table 10. Effect of zeolite supplementation on egg quality of laying hens drinking saline well water

\begin{tabular}{lccccccc}
\hline Traits & T & T1 & T2 & S & S1 & S2 & 土SE \\
\hline Egg weight (g) & $43.63^{\mathrm{c}}$ & $46.81^{\mathrm{ab}}$ & $46.38^{\mathrm{ab}}$ & $44.83^{\mathrm{bc}}$ & $45.61^{\mathrm{bc}}$ & $48.71^{\mathrm{a}}$ & 0.74 \\
Egg shape index (\%) & 74.65 & 76.95 & 76.60 & 74.97 & 75.23 & 77.32 & 0.86 \\
Shell weight (g) & $4.52^{\mathrm{c}}$ & $4.87^{\mathrm{ab}}$ & $4.61^{\mathrm{bc}}$ & $4.42^{\mathrm{c}}$ & $4.66^{\mathrm{bc}}$ & $5.13^{\mathrm{a}}$ & 0.10 \\
Shell (\%) & $10.39^{\mathrm{ab}}$ & $10.40^{\mathrm{ab}}$ & $9.95^{\mathrm{ab}}$ & $9.90^{\mathrm{b}}$ & $10.23^{\mathrm{ab}}$ & $10.55^{\mathrm{a}}$ & 0.17 \\
Albumen (\%) & 58.90 & 60.42 & 60.15 & 59.18 & 60.07 & 59.57 & 0.63 \\
Albumen weight (g) & $25.73^{\mathrm{c}}$ & $28.30^{\mathrm{a}}$ & $27.95^{\mathrm{ab}}$ & $26.39^{\mathrm{bc}}$ & $27.61^{\mathrm{ab}}$ & $29.00^{\mathrm{a}}$ & 0.58 \\
Yolk (\%) & 30.69 & 29.17 & 29.91 & 30.90 & 29.70 & 29.87 & 0.60 \\
Yolk/Albumen (\%) & 52.29 & 48.50 & 49.96 & 53.49 & 49.68 & 50.33 & 1.84 \\
Yolk weight (g) & $13.38^{\mathrm{b}}$ & $13.64^{\mathrm{ab}}$ & $13.86^{\mathrm{ab}}$ & $13.85^{\mathrm{ab}}$ & $13.56^{\mathrm{ab}}$ & $14.56^{\mathrm{a}}$ & 0.32 \\
Egg yolk index (\%) & 34.34 & 33.86 & 33.77 & 34.52 & 33.95 & 33.24 & 0.61 \\
\hline
\end{tabular}

$\mathrm{T}=$ hens drank tap water ( $265 \mathrm{ppm}$ total dissolved solids) and fed basal diet, T1 = hens drank tap water and fed diet containing $2 \%$ zeolite, T2 = hens drank tap water and fed diet containing $4 \%$ zeolite, $S=$ hens drank saline well water (3398 ppm total dissolved solids) and fed basal diet, $\mathrm{S} 1=$ hens drank saline well water and fed diet containing $2 \%$ zeolite, S2 $=$ hens drank saline well water and fed diet containing $4 \%$ zeolite, \pm SE $=$ standard error, ${ }^{\mathrm{a}, \mathrm{b}, \mathrm{c}}$ Means bearing different superscripts within the same row are significantly different $(\mathrm{P}<0.05)$.

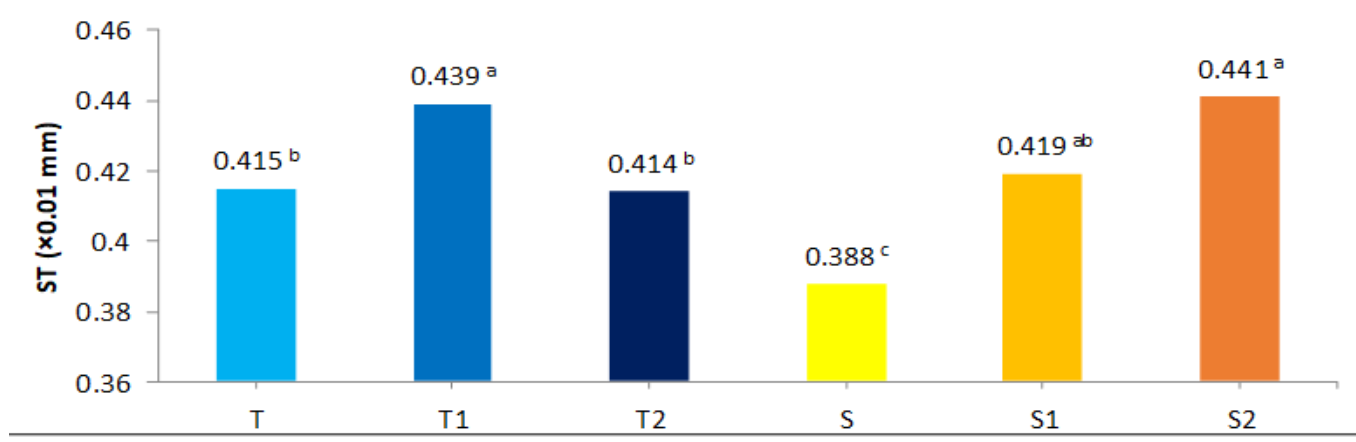

Figure 8. Effect of zeolite supplementation on shell thickness of laying hens drinking saline well water

$\mathrm{T}=$ hens drank tap water ( $265 \mathrm{ppm}$ total dissolved solids $)$ and fed basal diet, $\mathrm{T} 1=$ hens drank tap water and fed diet containing $2 \%$ zeolite, $\mathrm{T} 2=$ hens drank tap water and fed diet containing $4 \%$ zeolite, $S=$ hens drank saline well water (3398 ppm total dissolved solids) and fed basal diet, $\mathrm{S} 1=$ hens drank saline well water and fed diet containing $2 \%$ zeolite, S2 $=$ hens drank saline well water and fed diet containing $4 \%$ zeolite, ST= shell thickness, a, b, c Means bearing different superscripts are significantly different $(\mathrm{P}<0.05)$.

These results are agreeing with the results of Yoselewitz et al. (1988); Shafey (1993); Damron (1998); Pourreza and Edriss (1998) and Morsy et al. (2012) that reported sodium and chloride ions contribute to the production of defective shells in eggs from hens receiving $\mathrm{NaCl}$ supplements in the drinking water. The primary metabolic lesion associated with the poor egg shell quality which results from the intake of saline well water appears to be related to the supply of bicarbonate rather than calcium to the lumen of the shell gland for eggshell formation. A reduced activity of carbonic anhydrase in the shell gland mucosa is the particular importance. Several studies have been made on the effect of $\mathrm{NaCl}$ in drinking water, and the results indicated a reduction of calcium-binding protein (Balnave and Zhang, 2003) and the carbonic anhydrase enzyme which is important for shell formation (Balnave, 1993). This might have a negative impact on the egg shell quality. Poor shell quality was related to a reduced supply of bicarbonate, rather than with an effect on calcium in the lumen of the shell gland. However, the adverse effect of drinking saline well water on shell quality of hens may lead to an increase in egg breakage, then great economic losses in egg production (Balnave et al., 1989). On the other hand, temperature plays a role in aggravating the detrimental effects of saline water on egg shell quality since in the current and in the previous studies hens were exposed to severe heat stress.

This experiment clearly demonstrated that egg shell thickness was significantly decreased for hens drank saline well water without dietary zeolite supplementation. Similar trends were observed in other egg quality traits (Samara, 2003). However, adding zeolite to the diet of poultry improved the process of egg quality and shells strength without deleterious effects on the contents of the egg itself (Olver, 1997; Öztürk et al., 1998; Kermanshahi et al., 2011; Fendri et 
al., 2012). It has been reported that, feeding laying hens with zeolite improves eggshell quality (Roland et al., 1985; Rabon et al., 1991). The benefits effects of zeolite might depend on its concentration, the aluminum and phosphorus content of the aluminosilicate (Kermanshahi et al., 2011). On the other hand, natural zeolite a clinoptilolite-bearing rock material, were found to increase egg weight and albumin weight when it was incorporated in the hen's diet (Elliot and Edwards, 1991; Yannakopoylps et al., 1998).

\section{CONCLUSION}

Supplementation with zeolite (clinoptilolite) at level of $4 \%$ to the diets of hens reared under hot desert conditions and drinking saline well water could improve productive performance and eggshell quality characteristics.

\section{DECLARATIONS}

\section{Acknowledgments}

The authors are thankful to Dr. Ahmed Othman for his support and assisting in lab work. Deepest thanks are due to Dr. Ahmed Lotfy Hashem for facilitating the research work. Deepest thanks are due to Ras Sudr Station Staff for contributed during sample collection.

\section{Competing interests}

The authors declare that they have no conflict of interest with respect to the research, authorship, and/or publications of this article.

\section{Consent to publish}

All the authors approved and agreed to publish the manuscript and declared that this work has not been previously published elsewhere.

\section{Author's contribution}

Dr. Nagwa Abde El-Hady Ahmed designed the experiment, wrote and revised the article, Ahmed Abd-Elatif ElFar, wrote and revised the article, Dr. Ali Saber Morsy designed the experiment, laboratory analyses, statistical analysis, tabulation of experimental data, manuscript writing, commenting and approval, Dr. Amal Mohamed Hasan helped in statistical analysis, tabulation of experimental data and article writing; Dr. Khamis Refaay Said Emam designed the experiment, tabulation of experimental data, manuscript writing, commenting and approval; while, Mr. Hossam El-Din Mohamed Ibrahim helped in field study, collected data, laboratory analyses, manuscript writing. All authors have read and approved the final manuscript.

\section{REFERENCES}

Abbas TEE, Elzubeir EA and Arabbi OH (2008). Drinking water quality and its effects on broiler chick's performance during winter season. International Journal of Poultry Science, 7(5): 433-436. DOI: 10.3923/ijps.2008.433.436.

Abdel-Samee AM and El-Masry KA (1992). Effect of drinking natural saline well water on some productive and reproductive performance of California and New-Zealand White rabbits maintained under North Sinai conditions. Egypt Journal Rabbit Science, 2(1): 1-11. Available at: http://www.aun.edu.eg/env_enc/env\%20mar/env\%20oct/125-136.PDF.

Ahmed MM and Abdel-Rahman MA (2004). Effect of drinking natural saline ground water on growth performance behavior and some blood parameters in rabbits reared in new reclaimed lands of arid areas in Assiut Governorate. Assiut University Bulletin Environment Research, 7 (2): 125-135.

Andronikashvili TK, Pagava T, Kurashvili and Eprikashvili L (2009). Possibility of application of natural zeolites for medicinal purposes. Bulletin of the Georgian National Academy of Sciences, 3(2): 158-167. Available at: https://pdfs.semanticscholar.org/1c4e/2b6651c07ac5df53074bc7cc6fe64fb0e937.pdf.

Amal MH (2003). Some physiological and productive effects of promoting growth in rabbits drinking natural saline water. Ph.D. Thesis, Faculty of Agriculture. Cairo, University.

Amal MH (2013). Semen quality and hematology parameters of White leghorn cocks drinking saline water under hot desert $\begin{array}{llllll}\text { conditions. } & \text { Egypt. } & \text { Poultry } & \text { Science, } & 33(1): & 163-179 .\end{array}$ https://epsj.journals.ekb.eg/article_5383_53f9a45e6ea07f8eb3d0434d51b89e34.pdf.

Assad FM, Nassar AM, Hussein N and Abdelmageed SM (1997). Effect of saline water on some water on some biochemical parameters in sheep. Egyptian Journal Applied Science, 12: 1-13. DOI: 10.1292/jvms.17-0596

Balnave D (1993). Influence of saline drinking water on eggshell quality and formation. World Poultry Science Journal, 49: 109-119. DOI:org/10.1079/WPS19930009.

Balnave D and Zhang (2003). "Research Note: Responses of laying hens on saline drinking water to dietary supplementation with various zinc compounds", Poultry Science, 72: 603-606. DOI:https://doi.org/10.3382/ps.0720603

Balnave D, Yoselewitz I and Dixon RJ (1989). Physiological changes associated with the production of defective egg-shells by hens receiving sodium chloride in the drinking water. British Journal Nutrition, 61(1): 35 - 43. DOI:https://doi.org/10.1079/BJN19890090. 
Basha HA, Goma AA, Taha AE and Abou Elkhair R (2016). Effect of different forms of natural zeolite (clinoptilolite) on productive performance and behavioral patterns of broiler chickens. International Journal of Agriculture Science and Veterinary Medicine, 4(4): 1-11. DOI: https://www.researchgate.net/publication/315676631

Beltcheva MR, Metcheva M, Topashka-Ancheva N, Popov S, Teodorova JA, Heredia-Rojas AO, Rodríguez-de la Fuente and Rodríguez-Flores LE (2015). Zeolites versus lead toxicity. Journal of Bioequivalence \& Bioavailability, 7(1): 12-29.

Bintaş EM, Bozkurt K, Küçükyılmaz R, Konak M, Çınar H, Akşit K, Seyrek and Çatl AL (2014). Efficacy of supplemental natural zeolite in broiler chickens subjected to dietary calcium deficiency. Italian Journal of Animal Science, 13 : 3141. https://doi.org/10.4081/ijas.2014.3141.

Boyer J (2000). "Zeolite in Animal Nutrition", Undergraduate Seminar, http://animsci. agrenv.mcgi $1 \quad 1 \quad$.ca/ courses/ugradsem/00_01/Boyer_Sci.html

Colella C (2011). A critical reconsideration of biomedical and veterinary applications of natural zeolites. Clay Miner, 46: 295-309. https://doi.org/10.1180/claymin.2011.046.2.295.

Damron BL (1998). Sodium chloride concentration in drinking water and eggshell quality. Poultry Science, 77: 1488-1491. https://doi.org/10.1093/ps/77.10.1488

Debeic M (1994) “Influence of Clinoptiloliteson Chicken Growth”, Poultry. Abstract, Vol. 21, pp. 9-309.

Desheng Q, Fan L, Yanhu Y and Niya Z (2005) Adsorption of aflatoxin B-1 on montmorillonite. Poultry Science, 84: 959-961. DOI: $10.1093 / \mathrm{ps} / 84.6 .959$

Duncan DB (1955). Multiple range and multiple F-test. Biometrics, 11: 1-42.

Elliot MA and Edwards HM (1991). Comparison on the effects of synthetic and natural zeolite on laying hen and broiler chicken performance. Poultry Science, 70: 2115-2130. DOI:10.3382/ps.0702115

Eleroğlu HH and Yalçın AY (2011). Dietary effects of Ca-zeolite supplementation on some blood and tibial bone characteristics of broilers. South African Journal Animal Science, 41: 319-330.DOI: http://www.scielo.org.za/scielo.php?script=sci_arttext\&pid=S0375-15892011000400001

El-Wardany AM, Goher LM and Enab AA (1994). Effect of breed, laying period and selection for egg weight on egg Quality in two local breed of chickens. Egypt Poultry Science, 14: 23-49.

Emam KRS, Abdel-dayem AA and Abd El-Galil K (2019). Effect of zeolite supplementation on productive performance and blood constituents of broiler chickens under drinking saline well water conditions. Egyptian Poultry Science Journal, 39(1). http://www.epsj.journals.ekb.eg.

Emam KRS, Amal MH, Morsy AS and Abd El-Galil K (2017). Semen quality and hematological parameters of Sina cocks fed Atripex nummularia leaves meal under desert conditions. Egyptian Poultry Science, 37(IV): 1097-1111.

Evans M, Farrell DJ and Farrell DJ (1993). Are there economic benefits to adding zeolites to poultry diets';' Recent advances in animal nutrition in Australia, University New England, Armidale, Australia, 303-316. DOI: http://livestocklibrary.com.au/handle/1234/19714

Fendri I, Khannous L, Mallek Z, Traore AI, Gharsallah N and Gdoura R (2012). Influence of Zeolite on fatty acid composition and egg quality in Tunisian Laying Hens. Lipids in health and disease, 11(1): 71. Available at:http://www.lipidworld.com/content/11/1/71

Fethiere R, Miles RD and Harms RH (1994). The utilization of sodium in sodium zeolite A by broilers. Poultry Science, 73: 118-121. DOI: $10.3382 /$ ps.0730118

Fethiere R, Miles RD and Harms RH (1990). Influence of synthetic sodium aluminosilicate on laying hens fed different phosphorus levels. Poultry Science, 69: 2195-2198. DOI:10.3382/ps.0692195

Frost TJ, Roland DA, Barnes DG and Laurent SM (1992). The effect of sodium zeolite A and cholecalciferol on plasma levels of 1,25-dihydroxycholecalciferol, calcium and phosphorus in commercial leghorns. Poultry Science, 71: 886-893.

Guyton AC and Hall JE (2006). Textbook of Medical Physiology. $11^{\text {th }}$. WB Sounders Company, Philadelphia.

Ipek HM, Avci N, Aydilek and Yerturk M (2012). The effect of zeolite on oxidant/ antioxidant status in healthy dairy cows. Acta Veterinary Brno, 81: 043-047. DOI: https://doi.org/10.2754/avb201281010043

Julian RJ (1987). The effect of increased sodium in drinking water on right ventricular hypertrophy, right ventricular failure and ascites in broiler chickens. Avian Pathology, 16: 61-71. DOI.org/10.1080/03079458708436353.

Karadjole I, Tofant A, Vucemilo M and Hadziosmanovic M (1999). Effect of saline drinking water on acid-base balance and electrolyte levels in laying hen blood. Veterinary Medicine Czech, 44: 49-52. http://agris.fao.org/agrissearch/search.do? recordID $=$ CZ1999000585

Kermanshahi H, Haji Agha Jani E, Hashemipour H and Pilevar M (2011). Efficacy of natural zeolite and pigments on yolk color and performance of laying hens. African Journal of Biotechnology 1, 10:3237-3242. DOI: 10.5897/AJB10.1713

Leach RM, Brenda S, Heinrichs BS and Burdette J (1990). Broiler chicks feed low calcium diets. 1. İnfluence of zeolite on growth rate and parameters of bone metabolism. Poultry Science, 69: 1539-1543. DOI:10.3382/ps.0691539

Lotfollahian HF, Shariatmadari M, Shivazad and Mirhadi SA (2004). Study on the effects of two kinds of natural zeolite in diets on blood biochemical parameters, relative weight of body organs and broilers performance. Pajouhesh and Sazandegi, 64: 18-34. https://www.sid.ir/En/Journal/ViewPaper.aspx?ID=113672

Macháček MV, Večerek, Mas N, Suchý P, Straková E, Šerman V and Herzig I (2010). Effect of the feed additive Clinoptilolite (ZeoFeed) on nutrient metabolism and production performance of laying hens. Acta Veterinary Brno, 79: 29-34. DOI:https://doi.org/10.2754/avb201079S9S029 
Marai IFM, Ayyat MS and Abdel-Monem UM (2001). Growth performance and reproductive traits at first parity of New Zealand White female rabbits as affected by heat stress and its alleviation under Egyptian conditions. Journal of Tropical Animal Health Production, 33, 1-12. https://www.ncbi.nlm.nih.gov/pubmed/11770200

Miazzo RD, Peralta MF, Magnoli C, Salvano M, Ferrero S, Chiacchiera SM, Carvalho ECQ, Rosa CAR and Dalcero A (2005). Efficacy of Sodium Bentonite as a Detoxifier of Broiler Feed Contaminated with Aflatoxin and Fumonisin. Poultry Science, 84: 1-8. DOI:10.1093/ps/84.1.1

Miles RD and Henry PR (2007). Safety of improved Milbond-TX® when fed in broilers diets at greater than recommended levels. Animal Feed Science Technology, 138: 309-317. DOI: 10.1016/j.anifeedsci.2007.04.008

Miles RD, Harms RH and Laurent SM (1986). Influence of sodium zeolite A (EthacalR) on laying hen performance. Nutrition Reproductive International, 34: 1097-1103.

Milne DB (1996). Trace elements. In: Tietz Fundamentals of clinical chemistry. Burtis CA and Ashood ER (4th Edition.), 485-496.

Morsy AS, Mona MH and Amal MH (2012). Effect of natural saline drinking water on productive and physiological performance of laying hens under heat stress conditions. Egyptian Poultry Science, 32(III): 561-578.

Morsy AS, Manal MH, Gad- El-Moula, Dooa O, Hassan MS and Nagwa AA (2016). Blood picture, metabolites and minerals of rabbits as influenced by drinking saline water in Egypt. Global Journal of Advanced Research, 3(11): 1008-1017. DOI: http://gjar.org/publishpaper/vol3issue11/d628r62.pdf

Morsy AS, Manal MH, Gad- El-Moula, Dooa O, Hassan MS and Nagwa AA (2017). Effect of alternated drinkingsaline well water on the reproductive performance of rabbits. Egyptian Journal of Rabbit Science, 27 (1): 131- 148.

Morsy AS (2018). Effect of zeolite (Clinoptilolite) as a salinity stress alleviator on semen quality and hemato- biochemical parameters of Montazah cocks under South Sinai conditions. Research Journal of Animal and Veterinary Sciences, 10(2): pages 9-17.

Mumpton FA and Fishman PH (1977). The application of natural zeolites in animal science and aquaculture. Journal of Animal Science, 45 (5): 1188-1203. DOI: https://doi.org/10.2527/jas1977.4551188x

National Research Council (NRC) (1994). Nutrient Requirements of Poultry. $9^{\text {th }}$ edition. National Academic Press. Washington, D.C, 3(1): 101-101. Available at:https://www.scirp.org/(S(oyulxb452alnt1aej1nfow45))/reference/ReferencesPapers.aspx? ReferenceID=1955728.

Nik-Khan A and Sadeghi AA (2002). Natural Clinoptilolite-Tuff Effects on Health Homo-Immuno Parameters in Newborn Calves, Zeolite '02, 6th International Conference, Occurrence, Properties and Utilization of Natural Zeolites, pp: 253. https://www.researchgate.net/publication/288958500

Nikolakakis (2013). Effect of natural zeolite (clinoptilolite) on the performance and litter quality of broiler chickens. Turkish Journal of Veterinary and Animal Sciences, 37: 682-686. Available at:http://www.journals.tubitak.gov.tr/veterinary/

Nys Y (1999). Nutritional factors affecting eggshell quality. Czech Journal Animal Science, 44: 135-143. Available at: http://agris.fao.org/agris-search/search.do?recordID=CZ1999000678

Oğuz H and Kurtoğlu V (2000). Effects of clinoptilolite on performance of broiler chickens during experimental aflotoxicocis. British Poultry Science, 41: 512-517. DOI:10.1080/713654953

Olver MD (1997). Effect of feeding clinoptilolite (zeolite) on the performance of three strains of laying hens, British Poultry Science, 38, 220-22. DOI:10.1080/00071669708417973

Olver MD (1989). Effect of feeding clinoptilolite (zeolite) to three strains of laying hens. British Poultry Science, 36: 115-121. DOI:10.1080/00071668908417130

Ortatatli M and Oguz H (2001). Ameliorative effects of dietary clinoptiloliteon pathological changes in broiler chickens during aflatoxicosis. Research Veterinary Science, 71: 59-66. DOI: 10.1053/rvsc.2001.0487

Öztürk E, Erener G and Sarica M (1998). Influence of Natural Zeolite on Performance of Laying Hens and Egg Quality. Tr Journal Agricultuer Forest, 22:623-628. http://www.zeocat.es/docs/animalegglayinghens.pdf

Papaioannou D, Katsoulos PD, Panousis N and Karatzias H (2005). The role of natural and synthetic zeolites as feed additives on the prevention and/or the treatment of certain farm animal diseases: A review. Microporous and Mesoporous Material, 84: 161-170. DOI:https://doi.org/10.1016/j.micromeso.2005.05.030

Parlat SS, Yildiz AOH and Oguz H (1999). Effect of clinoptilolite on fattening performance of Japanese quail (Coturinix coturnix japonica) during experimental aflatoxicosis. British Poultry Science, 40: 495-500.

Pavelic K, Katic M, Serko V, Marotti T, Bosnjak B, Balog T, Stojkovic R, Radacic M, Kolic M and Poljak-Blazi M (2002). Immunostimulatory effect of natural clinoptilolite as a possible mechanism of its antimetastatic ability. Journal of Cancer Researsh Clinical Oncology, 128: 37-44. DOI: 10.1007/s00432-001-0301-6

Pavelic K and Hadzija M (2003). Medical applications of zeolites. In: Auerbach SM Carrado KA Dutta PK (eds.) Handbook of Zeolite Science and Technology, Marcel Dekker Inc., New York-Basel, pp: 1143-1174.

Pavelić KM, Hadžija L, Bedrica J, Pavelić I, Dikić M, Katić M, Kralj MH, Bosnar S, Kapitanović M, Poljak-Blazi, et al. (2001). Natural zeolite clinoptilolite new adjuvant in anticancer therapy. Journal of Molecular Medicine, 78: 708- 720.

Phillips TD (1999). Dietary clay in the chemoprevention of aflatoxin induced disease. Toxicology Science, 52: 118-126.

Potter BJ (1968). The influence of previous salt ingestion on the renal function of sheep subjected to intravenous hypertonic saline. Journal of Physiology, 194: 435-455. https://physoc.onlinelibrary.wiley.com/doi/pdf/10.1113/jphysiol.1968.sp008417

Pourreza J and Edriss MA (1998). Effect of Saline Drinking Water on Egg Shell Quality of Leghornand Native Hens. British Poultry Science, 35: 755-762.

Rabon HW, Roland DA SR, Bryant M, Barns DG and Laurent SM (1991). Influence of sodium zeolite A with and without pulletsized limestone or oyster shell on eggshell quality, Poultry Science, 70, 1943-1947. DOI:10.3382/ps.0701943 
Rizzi L, Simioli M, Roncada P and Zaghini A (2003). Aflatoxin B1 and clinoptilolite in feed for laying hens: effects on egg quality, mycotoxin residues in livers, and hepatic mixed-function oxygenase activities. Journal of Food Protection, 66: 860-865. Available at: https://www.ncbi.nlm.nih.gov/pubmed/12747697

Roland DA and Barnes DG and Laurent SM (1991). Influence of sodium aluminosilicate, hydroxy-sodalite, carnegicite, aluminum sulfate and aluminum phosphate on performance of commercial leghorns. Poultry Science, 70: 805-811. DOI:10.3382/ps.0700805

Roland DA, Laurent SM and Orloff HD (1985). Shell quality as influenced by zeolite with high ion-exchange capability. Poultry Science, 64: 1177-1187. DOI: 10.3382/ps.0641177

Safaeikatouli MY, Jafariahangari and Baharlouei A (2011). An evaluation on the effects of dietary kaolin and zeolite on broilers blood parameters, T4, TSH and growth hormones. Pakistani Journal of Nutrition, 10: 233-237. DOI: 10.3923/pjn.2011.233.237

Salari S, Kermanshahi H and Nasirimoghaddam H (2006). Effect of Sodium Bentonite and comparison of pellet vs mash on performance of broiler chickens. International Journal of Poultry Science, 5: 31-34. DOI: 10.3923/ijps.2006.31.34

Samara M (2003). Effect of feeding natural zeolite on performance of laying hens drinking saline water. An-Najah University Journal Research, (Master Science, Thesis), 17(2): 184-189. Available at: http://hdl.handle.net/20.500.11888/2055

SAS Institute (2004). SAS User's Guide: Statistics. Release 9.1. SAS Institute Incorporated., Cary, North Carolina.

Shafey TM (1993). Calcium tolerance of growing chickens: effect of ratio of dietary calcium to available phosphorus. Journal widget, 49, Issue 01. DOI:https://doi.org/10.1079/WPS19930002

Sheikhzadeh NM, Kouchaki M, Mehregan H, Tayefi-Nasrabadi B, Divband M, Khataminan AK, Oushani and Shabanzadeh S (2017). Influence of nanochitosan/ zeolite composite on growth performance, digestive enzymes and serum biochemical parameters in Rainbow trout (Oncorhynchus mykiss). Aquaculture Research, 48: 5955-5964. DOI:https://doi.org/10.1111/are.13418

Stino FKR, Goher NE, Kamar GAR and Hanash NA (1982). The effect of breed and housing system on the egg quality of White Baladi and Fayoumi hens in the subtropics. Egyptian Journal Animal Production, 23: 191-198.

Tata JR and Widnell CC (1966). Ribonucleic and synthesis during the early action of hormone. Biochemistry, 98: 604. Available at: https://www.ncbi.nlm.nih.gov/pubmed/5941352

Tserveni-Gousi AS, Yannakopoulos AL, Katsaounis NK, Filippidis A and Kassoli-Fournaraki A (1997) Some interior egg characteristics as influenced by addition of Greek clinoptilolitic rock material in the hen diet. Archive of fur Geflugelkunde, 61: 291-296. Available at: https://www.european-poultry-science.com/artikel.dll/1997-61-291-296_NTAwMzcxMg.PDF

Tukmechi A, Rahmati Andarani HR, Manaffar R and Sheikhzadeh N (2011). Dietary administration of beta-mercapto-ethanol treated Saccharomyces cerevisiae enhanced the growth, innate immune response and disease resistance of the Rainbow trout, Oncorhynchus mykiss. Fish and Shellfish Immunology, 30: 923-928. DOI:10.1016/j.fsi.2011.01.016

Underwood EJ and Suttle NF (1999). The mineral nutrition of livestock. $3^{\text {rd }}$ Edition. Chapter 1. New York, USA, 614.

Valpotić HS, Terzic S, Vince M, Samardzija R, Turk G, Lackovic B, Habrun D, Djuricic M, Sadikovic and Valpotic I (2016). In-feed supplementation of a clinoptilolite favorably modulates intestinal and systemic immunity and some production parameters in weaned pigs. Veterinary Medicine, 61: 317-327. https://www.semanticscholar.org/paper/In-feed-supplementation-ofclinoptilolite-modulates-Valpoti\%C4\%87-Terzi\%C4\%87/adef6b75248393980ecc4a6c81e86326c7ff9bc1

Ward TL, Watkins KL and Southern LL (1993). Interactive effect of sodium zeolite A and Eimeria acervulina infection on growth and tissue minerals in chicks. Poultry Science, 72(11): 2172-2175.

Watkins KL, Southern LL (1991). Effect of dietary sodium zeolites A and graded levels of calcium on growth, plasma and tibia characteristics of chicks. Poultry Science, 70: 2295-2303. DOI:10.3382/ps.0711048

Wawrzyniak AM, Kapica D, Stępień-Pyśniak R, Szewerniak A, Olejarska and Jarosz V (2017). Effect of feeding transcarpathian zeolite on gastrointestinal morphology and function in broiler chickens. Brazilian Journal of Poultry Science, 19(4): 737-746. DOI:http://dx.doi.org/10.1590/1806-9061-2016-0360

Wu QJ, Wang LC, Zhou YM, Zhang JF and Wang T (2013). Effects of clinoptilolite and modified clinoptilolite on the growth performance, intestinal microflora, and gut parameters of broilers. Poultry Science, 92: 684-692. DOI:10.3382/ps.2012-02308

Yannakopoylps AL, Tserveni-Gousi AS and Christaki E (1998). Effect of natural zeolite on yolk: albumine ratio in hen eggs. British Poultry Science, 39: 506 - 510.

Yoselewitz I, Balnave D and Dixon RJ (1988). Factors influencing the production of defective egg shell by laying hens receiving sodium chloride in drinking water. Nutrition Reports International, 38: 697-703. 